\title{
İran'da Yunus Emre İle İlgili Yapılan Akademik Çalışmalar
}

\author{
Academic Studies on Yunus Emre In Iran
}

\section{Zeynep Özel゙ $\odot$}

Öz

İran'da Yunus Emre ile ilgili yapılan çalışmaların oldukça sınırlı olduğunu söyleyebiliriz. Akademik olarak bakacak olursak Yunus Emre hakkında yapılmış bir teze rastlayamadık. Yunus Emre hakkında yazılan makalelerde ise Yunus Emre'nin genellikle Sa'dî ve Mevlânâ, nadiren de Hâfız ile karşılaştırıldığını görüyoruz. Yunus Emre'nin Mevlânâ'nın müridi olduğu iddiası da bulunmaktadır. İran’da birkaç makale ve çeviri eser dışında Yunus Emre ile ilgili telif bir kitaba rastlayamadık. İran'da Yunus Emre ile yapılan ilk tercümelerin 1970'li yılında başladığını, akabinde bu tercümelerin devam ettiğini görüyoruz. Son yıllarda da aşağıda belirtildiği üzere özellikle Yunus Emre'nin hayatına yönelik birkaç Türkçe eser daha Farsçaya kazandırılmıştır. Yunus Emre ile ilgili yazılan birkaç makalede ise hayatından ziyade Yunus Emre'nin eserlerinin karşılaştırmalı edebiyat kapsamında ele alındığı dikkati çekmektedir. Bazı çalışmalarda Yunus Emre'nin doğum yeri, mezhebi ve vefat yılı ile ilgili farklı görüşler dikkati çekmektedir. Biz bu çalışmamızda Yunus Emre ile ilgili İran'da yayımlanan eserleri ve Yunus Emre hakkında yazılan makaleleri tanıtıp geniş bir özet vermeye çalışacağız. Araştırmamızın İran'daki Yunus Emre çalışmalarına bir kapı aralaması dileğiyle.

\section{Anahtar Kelimeler}

Yunus Emre, İran, Sa'dî, Mevlânâ

\begin{abstract}
In Iran, studies about Yunus Emre are limited; moreover, to date, there have been no academic theses centered extensively on Yunus Emre. Nonetheless, there have been articles comparing Yunus Emre with Saadi and Rumi and rarely with Hafiz. Some studies also depict him as a follower of Rumi. However, except for a few articles and translated works, we have been unable to procure any copyrighted work on Yunus Emre. We have found that the first translations of Yunus Emre's works in Iran date back to the 1970s, and his works continue to be translated today. In recent years, Iranian researchers have translated some of the works on Yunus Emre's life into Turkish. It is noteworthy that in certain articles, Yunus Emre's works are discussed through the lens of comparative literature as opposed to revolving exclusively around his life. Moreover, scholarly opinions about Yunus Emre's birthplace, sect, and year of death typically differ. This study endeavors to introduce and broadly summarize Yunus Emre's works published in Iran. We hope that our study will facilitate the emergence of further Iranian studies centered on Yunus Emre's works.
\end{abstract}

\section{Keywords}

Yunus Emre, Iran, Saadi, Rumi

* Sorumlu Yazar: Zeynep Özel (Doktora Öğrencisi), İstanbul Üniversitesi, İlahiyat Fakültesi, Türk İslâm Edebiyatı Anabilim Dalı, Fatih, İstanbul, Türkiye. E-posta: zeynepeksiozel@gmail.com ORCID: 0000-0001-5838-9723

Atıf: Ozel, Zeynep. “İran'da Yunus Emre ile İlgili Yapılan Akademik Çalışmalar.” darulfunun ilahiyat 32, 'Yunus Emre' Özel Sayısı (2021): 129-148. https://doi.org/10.26650/di.2021.32.991920 


\section{Extended Summary}

In this study, we introduce Yunus Emre's works published in Iran and discuss articles on the poet, together with a broad summarization. Evidently, the earliest translations of Yunus Emre in Iran date back to the 1970s; translations of his works have continued ever since. In recent years, Iranian researchers have translated some of the works on Yunus Emre's life into Turkish.

In 1991, Nasîr Muhammedi wrote what emerged as one the first articles on Yunus Emre. Here, Muhammedi's depiction of the poet is based primarily on Turkish sources. H. Muhammedzâde Sadîk, a Tehran University professor known for his studies on Turkish poets, draws a different profile of Yunus Emre in the introductory section of his work Yunus Emre Divan, written and published by him in 2011. Here, he states that contrary to popular belief, Yunus Emre was a Shiite poet born in Hoy. Iranian studies typically mention Yunus Emre when comparing his works with those of Rumi and Saadi; furthermore, some studies depict Yunus Emre as a disciple or follower of Rumi.

Iranian articles on Yunus Emre and Rumi discuss these great poets in the context of wahdat al-wujud (The Unity of Being), soul, love, divine love, and moral treatises. Talat S. Halman, Mehmed Fuad Köprülü, Kadir Golkarian, Mustafa Tatçı, and İskender Pala's books about Yunus Emre, together with a story on the poet by Mustafa Özçelik, have been translated into Persian. In the articles written about Yunus Emre in Iran, Hicabi Kırlangıç and Ramazan Rezaei have compared Yunus Emre with Saadi. Ramazan Rezai also provides a comparison of the two poets' perspectives on the same topics and discusses their similarities. Hicabi Kırlangıç mentions that although there are similarities in Saadi's work Goulistan and Yunus's literary works, both the poets possess unique writing styles. He adds that Yunus Emre's works do not entail stories. Some articles suggest that Yunus Emre was literate enough to translate Saadi's poetry into Turkısh:

$$
\text { از جان بيرون نيامده جانانست آرزوست }
$$

Sen canından geçmeden cânân arzû kılursın

Bilden zünnar kesmeden îmân arzû kılursın

(Do you think you will reach your lover without giving up your life and cutting the zünnar on your waist)

A program on the works of Saadi and Yunus Emre was organized in Tehran in 2013; here, the similarities in and differences between Yunus Emre and Saadi's works were discussed.

Furthermore, Hosseini Arian ve Leily Abbasî Montazerî has written about love and Rumi-Yunus Emre; Fatima Heidari, Hakimi Dabiran, and Manzour Soltani-who have 
analyzed and compared Yunus Emre with Rumi and co-authored an article-compare the two poets on subjects such as unity, existence, and love. They also state that Yunus Emre was highly influenced by Rumi. In another article, Fatima Heidari deals with the subject of the soul in the Yunus Emre and Rumi's poems and states that Rumi played the role of a mentor to Yunus Emre:

In our opinion, even if Yunus Emre were influenced by Rumi, it would not be correct to perceive Yunus Emre as Rumi's follower. Rumi and Yunus Emre's works may come across as similar because all mystic poets typically share common perspectives; however, both the poets possess unique writing styles. Apart from all these academic studies, Yunus Emre Institute in Iran contributes to the promotion of Yunus Emre's works. In addition, Yunus Emre, a Türk Production, was screened with Persian subtitles in Iran.

In this article, we hope to facilitate a clearer perception of Yunus Emre in Iran by initiating the emergence of Iranian studies centered on Yunus Emre and broadly summarizing the existing articles on the poet. 


\section{Giriş}

İran'da Yunus Emre ile ilgili sınırlı sayıda çalışma yapıldığı dikkatleri çekmektedir. Yapılan çalışmalar genellikle Türk yazarların Yunus Emre'nin hayatı ve şiirleri ile ilgili kitapların Farsçaya tercümesi şeklindedir. Yunus Emre ile ilgili yazılan ilk makalelerden olan Nasîr Muhammedî’nin 1991 yılında yazdığı makalede, genellikle Türk kaynaklardan yola çıkarak bir Yunus Emre portresi oluşturduğu görülmektedir. Türk şairler hakkındaki çalışmalarılla tanınan Tahran Üniversitesi profesörlerinden H. Muhammedzâde Sadîk ise 2011 yılında kendi hazırlayarak yayımladığ 1 Yunus Emre Divân'ının giriş kısmında ve bir söyleşisinde farklı bir Yunus Emre profili çizerek bilinenin aksine, Yunus Emre'nin Hoy'da doğmuş Şii bir şair olduğunu ifade etmektedir. Yunus Emre'nin İranlı akademisyenlerin makalelerinde, özelikle Mevlânâ ve Sa'dî'nin eserleriyle karşılaştırılarak bazen de Mevlânâ'nın bir müridi ya da takipçisiymiş gibi ele alınarak işlendiği görülmektedir.

\section{İran'da Yunus Emre İle İlgili Çeviri ve Yayınlar}

İran'da Yunus Emre ile ilgili çalışmalarda telif eserlerden ziyade tercüme eserler dikkat çekmektedir. Yunus Emre'nin hayatı ve eserleriyle ile ilgili Türkçeden Farsçaya çevrilen kitapları şöyle sıralayabiliriz:

a. Talat S. Halman, Şair-i İnsangeray-ı Türk, (Hümanist Türk Şair) Tercüme: Vahid İmam, Tahran: Muassasah-i Farhangi-yi Mantaghey, h.ş.1355

b. Siyamak Hüseynalizâde, Işk Işı ğl , Yunus Emre'den Seçme İlahiler, (Fars Alfabesiyle Yazılmış Türkçe Şiirleri) Tebriz: İntişarât-1 Talâş̧ h.ş.1377.

c. Mehmed Fuad Köprülü, Sûfiyân-ı Nohustîn Der Edebiyat-ı Türk (Türk Edebiyatı'nda İlk Mutsavvıflar) Tercüme: Tevfîk Subhânî, Tahran: İntişârât-i Encümen Asar u Mefâhir-i Ferhengî, h.ş. 1385.

d. Kadir Golkarian, Gozide-i Eşâr-1 İrfani-yi Yunus Emre (Yunus Emre'nin İrfânî Şiirlerinden Seçmeler, Tebrîz: Neşr-i Yârân, h.ş. 1387

e. Mustafa Tatç1, Yunus Şair: Guzerî ber Zindegî ve Asâr Ahvâl-i Yunus Emre Nohustîn Şaîr-i Bozorg-i Edebiyyat-ı Türkî (Şair Yunus: Türk Edebiyatının İlk Büyük Şairi Yunus Emre'nin Eserlerine ve Hayatına Bir Bakış), Tercüme: Aydin Farangî, Erdebil: Neşr-i Unvan, h.ş. 1392

f. İskender Pala, Âteş, (Od) Tercüme: Kazem Azarî Sisi, Tebriz: Neşr-i Ahter, h.ş. 1395

g. Annemarie Schimmel, Ba Yunus Emre Der Rah" (Yunus Emre İle Yollarda), Almanca aslından tercüme: Mahrokh Maghsoudi, Tahran: Dayereh-i Farhang, h.ş. 1363 
h. Mustafa Özçelik, Raz-l Gol-i Sorh (Kırmızı Gülün Sırrı), Faslnâme-Gurûb, y1l: 1397 say1: 9

i. H. Muhammedzâde Sadîk, Yunus Emre- Divân-ı Eşâr-ı Turkî, Yunus Emre, Türkçe Şiirleri Divânı), Tahran: İntişarât-1 Tek Draht, h.ş. 1394

\section{Anılan Eserlerde Yunus Emre'nin Hayatına Bakış}

İran'da Türkçeden Farsçaya tercüme edilen eserlerde Yunus Emre'nin doğum yeri, yılı, mezhebi hakkında Türkiye' deki DİA maddesinden çok farklı bir bilgiye rastlanmamaktadır. ${ }^{1}$ Ancak Yunus Emre Divân'ını İran'da hazırlayıp yayımlayan Prof. Dr. Muhammedzâde Sadîk ise, bildiğimiz Yunus Emre'den farklı bir profil çizmektedir. Farsça Wikipedia da bu tartışmalı iddiayı baz almaktadır. ${ }^{2}$ Yunus Emre'nin doğum yerini Hoy şehri olarak kabul eden Prof. Sadîk, Unesco'nun Yunus Emre Y1lı ilan edecek kadar Yunus'un şöhretli oluşunu ise, Aleviler ve Ehl-i Hak müntesiplerinin törenlerinin köylerde ve bazı bölgelerde çok yaygın olmasına bağlamaktadır. Bu halkların genellikle okuma yazma bilmediklerini, törenlerinde Bektaşi şairlerinin nefeslerinin ve onlarla ilgili bilgilerin şifahi olarak nesilden nesle aktarıldığını ve Yunus Emre hakkında elimizde fazla yazılı kaynak olmadığ 1 için bu topluluklar eliyle Yunus Emre'nin tanındığını ifade etmektedir. Hâsılı bu şifahi bilgilerden yola çıkarak Yunus Emre'nin şimdilerde İran Batı Azerbaycan'da bulunan Hoy şehrinde doğduğunu, Taptuk Emre'nin emriyle daha sonradan Anadolu'ya geldiğini, Yunus Emre'nin kendisini Şii-Alevi olarak tanımladığını iddia etmektedir. ${ }^{3}$ Prof. Sadîk, Yunus Emre'nin şiirinin katman katman olduğuna değinip, bâtıni ifadelerin yoğunluğuna da dikkat çekerek şiirlerinde Taptuk Emre ve Mevlânâ'nın büyük etkisi olduğunu da söylemektedir. Yunus'un dili Azerbaycan âşıklarının dilidir, bu yüzden Azerbaycan halkı Yunus Emre'nin şiirlerini bugün bile rahatlıkla anlayabilir demektedir. Yunus Emre ve Mevlânâ'nın buluşması ile ilgili olarak ise bunun bir anlatıdan ibaret de olabileceğini, şiirlerinden anlaşıldığına göre Yunus Emre'nin Mevlânâ'dan çok daha rind, âşık ve sarhoş olduğunu söyleyerek, ilginç bir şekilde Yunus Emre'nin reenkarnasyona inanan aşırı uçlardaki ehl-i hak Alevilerinden olduğu iddiasını ise s1k s1k yinelemektedir. ${ }^{4}$

1 Mustafa Tatçı, Yunus Emre, "Türkiye Diyanet Vakfi İslam Ansiklopedisi”, (İstanbul: TDV Yayınlar, 2013), 43: 600

2 https://fa.wikipedia.org/wiki/\%DB\%8C\%D9\%88\%D9\%86\%D8\%B3_\%D8\%A7\%D9\%85\%D $8 \% B 1 \% D 9 \% 87$

3 Mahnâme-i Şems Nigâr, (Hoy: h.ş. 1395),4 (Ayrıca bu söyleşinin yer aldığı link kaynakçada verilmiştir)

4 Mahnâme-i Şems Nîgâr, (Hoy: h.ş. 1395),4 
Oysa bu konu Mehmet Fuad Köprülü’nün Türk Edebiyatında ilk Mutasavvıflar isimli kitabında şöyle geçmektedir:

"Yunus Muhyiddin Arabî ile Celâleddin Rûmî'de tesadüf edilen ve ulemay1 rusûm'un büyük bir kısmı tarafından bile -isterse te'vil yoluyla olsun- şer'i hükümlere aykırı görülmeyen esasların dışına çıkmadığı için onu Bâtınilikten yani "akaid-i resmiyeye uygun olmayan mezhep erbabından saymak tamamiyla yanlıştır." 5

Mahrokh Maghsoudi ise Yunus Emre'yi tanıttı̆̆ı makalesinde Doğum tarihini 1240 vefat tarihini de 1320 olarak aldığı Yunus Emre'nin coşkulu, hümanist, Allah aşkıyla dolu büyük bir Türk şairi olduğunu söylemektedir. ${ }^{6}$

İranlı bir başka akademisyen olan Nâsır Muhâmmedî ise Abdulbâki Gölpınarı'nın eserlerine de atıf yaparak yazdığı makalesinde, Yunus Emre'yi 11.yy. Fars şairi Baba Tahîr'e benzeterek, onun da kalender meşrep Baba Tahîr gibi ovalardan dağlardan gezerek göçebe bir hayat yaşadığını ve halk tarafından çok sevildiğini belirtmektedir. Muhammedî makalesinde Yunus Emre'nin doğum yerini Prof. Sadîk'in iddiasının aksine Sarıköy olarak almaktadır. ${ }^{7}$ Efsaneleşen bir karakter olması hasebiyle Yunus Emre'nin Türkiye'de en az on beş şehirde kabri ya da makamı oluşuna değinmektedir. ${ }^{8}$ Yazar Yunus Emre'nin kıtlık döneminde Hacı Bektaş Veli’ye gidişini ve buğday isteyişine de yer vererek, Hacı Bektâş’ın "Nefes mi Buğday mı" sorusunu, "Yemek mi istiyorsun yoksa hakikatin sırrını mı" şeklinde yorumlamaktadır. Makalesinde Yunus Emre'nin defalarca Mevlânâ'nın semâ törenlerine katıldığını da belirterek, aşağıda ayrıntılı bir şekilde değineceğimiz Mevlânâ ve Yunus Emre'nin tanışıklı̆̆g konusunda N. Muhammedî şöyle demektedir:

“Köstendilli Süleyman Şeyhî’nin Bahrü'l-Velâye isimli eserinde geçtiğine göre, Yunus Emre Mevlânâ'ya 'Mesnevîyi sen mi yazdın' diye sorunca, Mevlânâ da 'Evet' demiş, Yunus da bunun üzerine o kadar eseri boşuna yazmışsın, aslında şunu demek istemişsin anlamında: 'Et ü deri büründüm geldüm size göründüm.'

5 Mehmet Fuad Köprülü, “Türk Edebiyatında İlk Mutasavvfflar”, (İstanbul: Alfa Yayınları, 2017), 443

6 Makhrouh Maksoudî, "Yunus Emre, Şâir-i Türk”, (Meşhed: Mecelle-i Tahsisi-i Zebân u Edebiyâ-1 Dânişkede-i Edebiyât u Ulûm-i İnsânî, h.ş. 1383), 3: 60

7 Nâsîr Muhammedî, "Yunus Emre Şair-i Şuride-i Türk, (Neşr-i Nâme-i Ferheng”, h.ş. 1370) 4: 86

8 Nasîr Muhmmedî, Yunus Emre, s.86. Ayrıca Bu konu hakkında ayrıntılı bilgi için bkz. Mehmet Fuad Köprülü, "Türk Edebiyatında İlk Mutasavvıflar”, 382-387

9 (Makalelerde Yunus Emre dizelerinin Farsça çevirilerini yeniden Türkçeye çevirirken Mustafa Tatçı'nın hazırladığı Yunus Emre Divân'ından kontrol yapılmıştır.) Mustafa Tatçı, T.C. Kültür ve Turizm Bakanlığl, e-kitap, ISBN 978-975-17-3342-9, şiir no.178 
Diye karşı1lı vermiş." Ancak makalenin yazarı N. Muhammedî yaşça Mevlânâ' dan küçük olan Yunus Emre gibi bir dervişin edep sınırlarını zorlayan böyle bir ifade kullanmasının mümkün olmadığını da makalesinin devamına eklemiştir. Yazar, Prof. Sadîk'in Yunus Emre'nin Şii olduğu iddiasının aksine, Yunus Emre'nin Sünni bir şair olarak Babaîler topluluğunun bir müridi olduğunu iddia etmenin zor olduğunu da makalesinde belirtmektedir. Bir başka yazar Ramazan Rezaei ise Yunus Emre'nin vefat tarihi ile alakalı ihtilaflara dikkat çekerek 707 / 1328 tarihinde vefat etmiş olabileceğini söylemiştir. ${ }^{10}$

Ama DİA'da Yunus Emre maddesini yazan Mustafa Tatçı, tüm ihtilaflı tarihlerin sonucunda M. Fuad Köprülü’nün Adnan Erzi'nin bir belgeyi neşretmesinin ardından Yunus Emre'nin vefat tarihini 1320 olarak kabul ettiğini söylemektedir. ${ }^{11}$

Nâsır Muhammedî, Yunus Emre'nin çok fazla okuma yazma bilmediği iddialarına rağmen, derin ve güçlü şiirler yazdığını, 81 şiirinin ilahi olarak bestelendiğini ifade etmektedir. Yunus Emre'nin Hâfız-1 Şîrâzî'den ve Sa'dî' den etkilendiği anlaşılan dizeleri sebebiyle Farsça biliyor olması gerektiğini söyleyerek bu dizelerden örnekler vermektedir. ${ }^{12}$ Muhammedî’nin örnek gösterdiği bir beyit şöyledir:

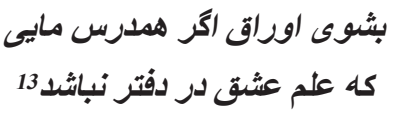

"Ders arkadaşımızsan sil sayfaları

Zira aşk ilmi defter üzerinde yer almaz”" (Sa'dî)

\section{Iy çok kitâblar okuyan sen kim dutarsın bana dak}

\section{Tâ bilesin sırrı 'tyan gel 'ışktan okı bir varak. (Yunus Emre) ${ }^{14}$}

Yine araştırmac1, Yunus Emre'nin, Sa'dî’nin bir beytini de tercüme ettiğine işaret etmektedir:

10 Ramazan Rezaei, "Der Amedî-yi Ber Mezamin-i Ahlaki-yi Ez Didgâh-ı Sa'dî ve Yunus Emre”, (Mecmue-i Dânişgâh-i Muhakkık-i Erdebilî: h.ş.1394), 1-10

11 Mustafa Tatçı, Yunus Emre, "Türkiye Diyanet Vakfi İslam Ansiklopedisi”, ( İstanbul: TDV Yayınlar, 2013), 43: 600

12 Nâsîr Muhammedî, Yunus Emre, s. 88

13 Hâfiz-1 Şîrâzî, Divân, Hâfiz-ı Şîrâzî, Divân, Haz. Muhammed Kazvinî, Kâsım Ganî, (Intşarat-ı Kaknüs, h.ş.180 gazel no: 162 )(Makalelerde geçen bütün beyitler, kaynakçada geçen kaynaklardan kontrol edilmiştir)

14 Yunus Emre, Divân, şiir no: 130 


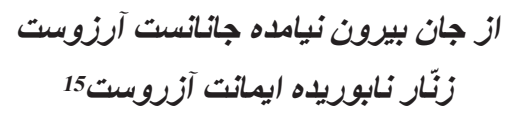

Sen canından geçmeden cânân arzû kulursın

Bilden zünnar kesmeden îmân arẑ̂u kılursın ${ }^{16}$

Yazar bu etkileşimlerden yola çıkarak Yunus Emre'nin ümmi olmak bir yana Farsçayı da tercüme yapacak kadar bildiğini de eklemektedir. ${ }^{17}$

\section{Çalışmalarda Sa'dî Şirâzî ve Yunus Emre Mukayesesi}

İran'da Sa'dî ve Yunus Emre'yi karşılaştırmalı olarak ele alan, aşağıda özetini vermeye çalışacağımız Hicabi Kırlangıç ve Ramazan Rezaei'nin makalesi dışında, 2013 y1lında Tahran Şehr-i Kitâb Merkezi'nde Sa'dî Şirâzî ve Yunus Emre'nin ele alındığ 1 bir program düzenlenmiştir. Konferansa katılan Hicabi Kırlangıç, aralarındaki bazı benzerliklere rağmen Yunus Emre'nin doğrudan Sa'dî'den etkilenmiş olduğunu söyleyemeyiz diyerek, Sa'dî'nin Yunus Emre kadar saf mistik bir şair olduğunu belirtmenin zor olduğunu ifade etmiştir. Programda konuşan N. F. Mâlik Marzbân ise hem Sa'dî'nin hem de Yunus Emre'nin içten bir dille dinleyiciyi/ okuyucuyu önemseyen ve muhatap alan samimi bir dil kullandıklarını belirtmiştir.

Önemli bir konuyu ayrıntılı bir şekilde ele alması ve İran'da yayımlanmış olması bakımından Hicabi Kırlangıç'ın “Şekil ve Muhteva Bakımından Yunus Emre ve Sa'dî'nin Eserlerinin Karşılaştırılması” isimli makalesi ile Ramazan Rezai'nin "Sa'dî ve Yunus Emre'nin Perspektifinden Ahlaki Mazmunlara Giriş" makalesinin geniş bir özetine bu bölümde yer vermenin faydalı olacağı kanaatindeyiz.

Rezaei makalesinin giriş kısmında Sa'dî’nin ahlakî düşüncenin temsilcisi sayıldığını, Müslüman, kâfir ya da günahkâr olsa da tüm insanların önemli olduğunu düşünen Sa'dî'nin hümanist bir şair sayılabileceğini, insanları ahlaki hasletlere sahip olmaya çağııırken adeta kendi el-Medinetü'l Fâzıla'sının peşinde olduğunu vurgulamaktadır. $^{18}$

Hicabi Kırlangıç ise makalesinde Fars Dili'nin en önemli isimlerinden Sa'dî’nin hayatı hakkında nispeten elimizde sağlıklı bilgiler mevcutken, Yunus Emre hakkında genellikle şifahi olarak elde edilen bilgiler olduğunu belirtmektedir. Son yıllarda yapılan çalışmalarla Yunus Emre hakkında elde edilen bilgilerin Sa'dî’nin hayatı

15 Sa'dî, Külliyât-ı Sa'dî, no:120 s.589

16 Yunus Emre, Divân, no:255

17 Nasîr Muhammedî, Yunus Emre, s.88

18 Ramazan Rezaei, Sa'dî ve Yunus Emre, s.2 
hakkında elimizde olan bilgilerle kıyaslanamayacağına değinerek şöyle demektedir: Sa'dî tasavvufi ve ahlaki konuları çok güzel bir şekilde ele almasına rağmen Yunus Emre gibi bir sufî olarak bilinmemektedir. Yunus Emre kendi manevi tecrübelerin eserlerine yansıtmıştır. Bu ayırımdan sonra eserlerini inceleyecek olursak Sa'dî-i Şîrâzî hem nesir hem şiir alanında oldukça yetkin bir isimdir. Onun döneminde Farsça elit ve edebî bir dildir. O dönemlerde Anadolu Türkçesi ise edebi bir dil olarak yeni yeni kullanılmaktadır. Böyle bakınca Yunus Emre'nin Türkçeye katkısı oldukça önem taşımaktadır. Firdevsî’nin Farsçaya etkisiyle Yunus Emre'nin Türkçeye etkisini benzetirsek, ele aldıkları konulardaki farklılığa rağmen yanlış olmaz."19

Yunus Emre, Türkçe yazan en önemli Anadolu şairlerindendir. Sade ve dervişane bir yaşantısı vardır. Ondan bize kalan iki eserinden biri gazellerden ya da başka bir deyişle tasavvufi-dini şiirlerden oluşan şiirleri, diğeri de mesnevî tarzında yazılmış ve 600 beyitten oluşan Risaletü'n-Nushiyye isimli eseridir. Bu iki eser o dönemi Türkçe'nin özelliklerini anlamamız bakımından da oldukça önemlidir. ${ }^{20}$

\section{Yunus ve Sa'dî’nin Eserlerinin Karşılaştırılması}

Farsça ve Türkçe birbiriyle köklü bir etkileşim halinde olan iki dildir. Sa'dî ve Yunus Emre sehl-i mümteni şairi olarak ele alınmaları ve işledikleri konuların benzerliği sebebiyle de birbirlerini hatırlatmaktadırlar.

Ramazan Rezaei Yunus Emre'nin eserleriyle ilgili şöyle demektedir:

"Yunus Emre şiirlerinde kendisini "Kul Yunus", "Âşsłk Yunus” gibi tanımlarla ifade eder. Onun şiirleri kendine özgü kullandığı özel terimlere sahiptir. Varlık düşüncesini, ilim, aşk ve ahlak felsefesini incelikle işlemiş, üzüntüyü de sevinci de göz alıcı bir şekilde ele alabilmiştir."’21

Hicabi Kırlangıç ise Sa'dî'nin çokça seyahat ettiğini, farklı ülkelere giderek o kültürleri yakından tanıma firsatı bulabildiğini, Bostan isimli eserini bu seyahatlerden döndükten sonra yazdığını, Gülistanı da Bostan'dan hemen sonra yazdığını belirterek eklemektedir:

“Sa'dî’nin eserlerinde Farsçanın zenginliği yanında, Arap şiir ve kültürünün de etkisi görülür. Bu şekliyle Sa'dî’nin şiirleri de Yunus Emre'nin şiirleri gibi İslam Dünyasının ortak birikimine örnek teşkil etmektedir. Sa'dî hacimli bir divana

19 Hicâbî Kırlangıç, Asâr-ı Yunus Emre ve Sa'dî Ez Nazar-ı Sûret ve Muhtevâ, (Şî̀̂az: Neşriye-yi Sa'dî Şinâsî, h.ş.1393), 17:31

20 Hicabi Kırlangıç, Yunus Emre ve Sa'dî, s. 33

21 Ramazan Rezaei, Sa'dî ve Yunus Emre, s.3 
sahiptir. Kasideleri, gazelleri rubâileri, mülemmaları diğer pek çok büyük şaire ilham olmuştur. Sa'dî Arap şiirinden de etkisiyle aşıkâne gazellerin en önemli temsilcilerinden biridir. Mesnevî tarzında yazılan Bostan isimli manzum eseri on bölümden oluşmaktadır. Bostan eğitici bir kitaptır. Gülistan ise Bostan'ın tamamlayıcısı gibidir. Manzum mensur karışık bir eserdir ve sekiz bölümden oluşmaktadır. Bu iki kitap genellikle ve de Türkiye'de de bir arada ve güzel ciltli kapaklarla basılmaktadır. Sa'dî’nin aynı zamanda Beş Meclis ve Akıl ile Aşk Meclisi isimli tasavvufi bir eseri de vardır."22

Hicabi Kırlangıç makalesine şöyle devam ediyor:

"Bazı araştırmacılar Yunus Emre'nin Arap ve Fars şairlerine aşina olduğunu söylemişlerdir. ${ }^{23}$ Böylece Yunus Emre'nin şiirlerinde onların da etkisi görülmektedir. Şiirlerinde aruzu başarılı denebilecek bir şekilde kullanmış, Arapça ve Farsça günlük dilde çok da kullanılmayan terkipleri ustalıkla kullanmıştır. Ama yine de Yunus Emre diğer şairlerle çok fazla karşılaştırılarak çalışılmadığı için şiirindeki bu etkilerin boyutunu tam olarak bilmiyoruz. Bu anlamda Yunus Emre ve Sa'dî'nin şiiri birbirine çok benziyor diyemeyiz. Ele aldıkları konular, ahlak, iyiliğe davet, dini ve tasavvufi konulara değinmeleri açısından bir benzerlik olsa da tam bir benzerlikten söz edemeyiz. Örneğin Yunus Emre'nin eseri Risâletü’n-Nushiyye ile Sa'dî'nin Bostan adlı eserini başlıklar halinde karşılaştıracak olursak aralarında benzerlikler şöyledir:

1- İki eser de öğreticidir.

2- İki eser de manzum ve mesnevî tarzında yazılmıştır.

3- İki eser de aruz vezniyle yazılımıştır ama vezinleri birbirinden farklıdır:

Bostan'ın Vezni: Fecûlün/fecûlün/fecûlün/fe'ûl; Risâletü'n-Nushiyye'nin vezni: Mefầîlun/mefầiilûn/fecûlün

4- Her iki eser de bölümlere ayrılmıştır:

Bostan on bölüme, Risâletü’n-Nushiyye ise altı bölümden oluşmaktadır. Bölüm başlıklarının isimleri birbiriyle benzerlik göstermektedir:

Bostan'ın Alt Başlıkları:

Adalet ve Tedbir/ İyilik /Aşk / Sarhoşluk ve Coşku / Tevazu / Rızâ / Kanaat / Terbiye/ Şükür/ Tövbe ve Doğru Yol / Münacât;

22 Hicabi Kırlangıç, Sa'dî ve Yunus Emre, s. 33

23 Hicabi Kırlangıç, Sa'dî ve Yunus Emre, s. 36 
Risâletü’n-Nushiyye'nin Alt Başlıkları:

Ruh ve Akı1/ Kibir ve Kanaat/ Huşu ve Gazap/ Sabır/ Cimrlik ve Hased/ Gıybet ve Suçlamak) İki eserdeki bölüm başlıklarının benzerlik göstermesi, içerik olarak da benzediği anlamına ya da iki eser arasında bir alışveriş olduğu anlamına gelmemektedir. Bostan daha hacimli ve hikâyelerle dolu bir eserdir. Oysaki Yunus Emre'nin hiçbir eserinde hikâye yoktur. Sa'dî'nin Gülistan adlı eserinin de Yunus Emre'nin herhangi bir eseriyle benzerliği yoktur.

Risâletü’n-Nushiyye'nin kendine özgü, hiçbir eserle birebir benzerliği olmayan bir eser olduğunu söyleyebiliriz. En önemlisi de Risâletü'n-Nushiyye'nin Anadolu Türkçesiyle yazılmış ilk müstakil örneklerden biri oluşudur. Yunus Emre taklitçi ve takipçi bir şair değil, kendine özgü üslubuyla şiir söyleyen bir şairdir.

Sa'dî'nin bazı şiirlerinde Arap şiirlerinin etkisi görülebilmektedir. Yunus Emre'nin bazı şiirlerinde belli belirsiz Mevlânâ'nın etkisi görülebilse de bariz bir etkileşimden bahsedilememektedir."

\section{Sa'dî ve Yunus Emre'nin ortak konu başlıkları}

Ramazan Rezaei ise makalesinde Sa'dî ve Yunus Emre'nin eserlerinde şu ortak başlıkları tespit etmiştir:

\section{İman}

Sa'dî’ye göre eşref-i mahlûkât olan insanın en önemli kazanımı dindar olabilmesidir. Her an Allah'ın huzurunda olduğunu idrak edebilen bir insan bu farkındalıktan huzur duyacak ve davranışları da buna göre şekillenecektir:

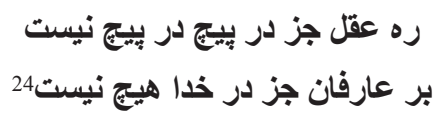

Aklın dolambaçlı yollardan başka yolu yoktur

Arifler nezdindeyse Allah'tan başkası yoktur

Yunus Emre'ye göre de imanın tecellilerinden biri aşktır:

\section{Allah benüm didigüne virmişdür 'ışk varlıgını ${ }^{25}$}

\section{Gurur ve Kibir}

Gurur ve kibir insan tabiatında hoş durmayan bir özelliktir. Sa'dî’ye göre olgun insanda gurur olmaz:

24 Sa'dî, Külliyât-ı Sa'dî, s.393

25 Yunus Emre, Divân, no:65 


$$
\begin{gathered}
\text { خدابينى از خويشتن دنيا ره دين مجور مبن مجو } 26 \\
\text { Dïnyanın kibriyle din arama } \\
\text { Kendini beğenmişlikle Cemâli arama }
\end{gathered}
$$

Yunus Emre:

Miskîn ol yâre miskin gide senden kibr ü kîn

Rûzigâr gelür geçer pes kime kalasıdur ${ }^{27}$

İlim ve Amel

Amel ve ilim doğru kullanıldığı takdirde manevi tekâmülü sağlar ve dünya ahiret hayatını kazanmaya vesile olur:

$$
\text { با علم اكر عمل نـكنى علم ندانم بجز عمل بـ برى } 28
$$

İlim ağacının amelden başka meyvesi var mı bilmiyorum

İminle amel etmezsen meyvesiz dal gibi olursun

Yunus Emre:

'Illim 'ilim bilmekdür 'ilim kendün bilmekdür

Sen kendüni bilmezsin yâ niçe okumakdur ${ }^{29}$

\section{Gaflete Düşmemek}

Sa’ dî İnsanın gafil olmaması için masivadan uzak ve ehl-i dil olması gerektiğini söyler.

$$
\text { تا كر عاقل و هشبيار و ز دل خبردار }
$$

Akıllı, bilge ve gönül gözün açık olursa

O zaman sana âdem derler hayvandan aşağı olmazsın

26 Sa'dî, Külliyat-ı Sa'dî, s.405

27 Yunus Emre, Divân, no: 64

28 Sa'dî, Külliyât-l Sa'dî, no.32 s.991

29 Yunus Emre, Divân, no: 91

30 Sa'dî, Külliyât-ı Sa'dî, s. 900 
Yunus Emre de asıl akı1lı insanın gönlü açık, Allah'ın velisi olan insan-1 kâmil olduğunu söyler:

\section{Sen seni ne sanursan ayruga da ant san}

Dört kitâbun ma'nîsi budur eger vartsa ${ }^{31}$

\section{Fütüvvet}

Sa'dî de Yunus Emre de diğerkâmlığı, insanların derdiyle hemderd olmayı, insanlara karşı cömert ve yardımsever olmayı önemsemişlerdir. Fütüvvet sahibi Hakk'ın rızasını gözetir:

Yunus Emre:

\section{Bir hastaya vardunısa bir içim su virdünise}

\section{Yarın anda karşu gele Hak şarâbın içmiş gibi ${ }^{32}$}

Ramazan Rezaei makalesinde bu ortak başlıkları örneklendirdikten sonra bu iki büyük şairin de toplumu yozlaşmaktan korumak için nasıl benzer bir yönlendirmeye gayret ettiklerini, 72 millete de hoş görüyle yaklaşarak insanın hem bireysel hem toplumsal gelişime katkı sağlayabilecekleri ortak mesajına dikkat çekerek ${ }^{33}$ makalesini bitirmektedir. Hicabi Kırlangıç'ın makalesiyle bu makaleyi karşılaştıracak olursak, Ramazan Rezaei iki şair arasındaki benzerlikleri ve ortak konu başlıklarını ele almaktadır. Hicabi Kırlangıç ise iki şairin ortak yönlerinin yanı sıra, farklı yönlerini de ele alarak, Sa' dî’nin de Yunus Emre'nin de başlı başına özel bir üslubu olduğunu ifade etmektedir.

\section{Çalışmalarda Mevlânâ ve Yunus Emre Mukayesesi}

Aynı dönemde yaşadıkları için Mevlânâ ve Yunus Emre'nin görüştüğüne dair rivayetler vardır. Yunus Emre'ye ait olan,

\section{Mevlânâ Hüdâvendigâr bize nazar kulalı}

Onun görklü nazarl gönlümüzz̈̈n aynasıdır ${ }^{34}$

dizesi de Yunus Emre'nin Mevlânâ'ya duyduğu sevginin ve hürmetin işaretidir.

Şiirlerinde Mevlânâ'ya karşı büyük bir saygı beslediği ve üzerinde Mevlânâ'nın

31 Yunus Emre, Divân, no: 299

32 Yunus Emre, Divân, no: 388

33 Ramazan Rezaei, Sa'dî ve Yunus Emre, s. 9

34 Yunus Emre, Divân, no.64 
himmeti olduğuna inandığı anlaşılsa da, Mevlânâ'nın onun şiirine tam olarak ne şekilde etki ettiği hakkında elimizde yeterli çalışma yoktur.

Yunus Emre'nin şiirindeki bazı mazmunlar Mevlânâ'nın Divân-1 Kebîr'deki bazı gazellerini hatırlatmaktadır: ${ }^{35}$

\section{Iy 'âşsıan iy 'âşıkan 'ışk mezhebi dîndür bana}

Gördi gözüm dost yüzüni yas kamu dügündür bana ${ }^{36}$

\section{Yunus Emre}

Mevlânâ’nın Divân-1 Kebîr'inden.

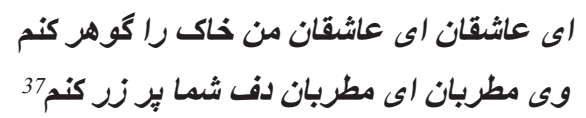

Ey aşıkan Ey aşıkan ben topră̆ı cevher yaparım

\section{Ey mutriban Ey mutriban sizin definizi alttnla doldururum}

Hosseini Arian ve Leily Abbasî Montazerî’nin birlikte yazdığı Mefhum-i Işk Ez Didgâh-1 Mevlânâ ve Yunus Emre isimli makale, iki büyük şairin bakışıyla aşkı ayrıntılı bir şekilde incelemektedir. Makale, Mevlânâ'nın hem yaşadığı dönemde hem de sonrasında, arifler ve şairler üzerinde oldukça etkili olduğunu ifade etmektedir. Anadolu'ya göç etmesinin Türk şairler için bir firsat oluşunu ve Yunus Emre'nin de onun etkisinde kaldığına yer verip şöyle devam etmektedir: "Yunus Emre Moğol istilası zamanında karışık bir dönemde doğmuş, Hacı Bektaş, Mevlânâ, Taptuk Baba zamanında yaşamış ve onlardan feyiz almıştır." 38

Makalede Mevlânâ'nın aşkı derin bir şekilde ele alışı işlenmekte, Mevlânâ ve Yunus Emre'nin bazı üslup benzerlikleri ise Yunus Emre'nin Mevlânâ'nın irfani ekolünden etkilenmesi olarak yorumlanmaktadır. İki şairin de aşkı ele alış şekli ve dünyaya bakışları benzerlik göstermektedir. Aşk iki taraflı olmalıdır. Âşık ve maşukun birbirine olan kavuşma çabası vuslata ulaşmakta en önemli adımdır. Âşık ve maşukun ikisi de vuslatın eksikliğin hissetmelidir. Makale karşılıklı örneklerle devam ederek bu benzerliği işlemektedir:

35 Hicabi Kırlangıç, Yunus Emre ve Sa'dî, s. 35

36 Yunus Emre, Divân, no:7

37 Mevlânâ, Divân-ı Kebir, no:1374

38 Arian Hosseini - Montazeri ve Leily Abbasî, Mefhum-i Işk Ez Dîdgâh-ı Mevlânâ ve Yunus Emre,( Faslnâme-yi Motaale-yi Edebiyyat-ı Tatbikî: h.ş. 1393, yıl:8, sayı: 29 s. 108 
Mevlânâ:

$$
\text { كيج نه عاشق خود نباشد وصل جو }
$$

Aşık kendi başına vuslatı arayamaz

Maşuku da bizzat onu aramadıkça

Yunus Emre:

$$
\text { Ol dost bize gelmezise ben dosta girü varayın, }
$$

Çeküben cevr ü cefâyı dostumun yüzin göreyin ${ }^{40}$

Aşk o kadar önemlidir ki elest bezmi ve tüm âlem onun üzerine kurulmuştur:

Mevlâna:

$$
\begin{aligned}
& \text { من بدان افراشتم جرخخ سنى } \\
& \text { تا علو عشق را فهمى كنى } 41
\end{aligned}
$$

Ben o yüce arşı iyice yükselttim $k i$

Aşkın gücünü hakkılla anlayabilesin

Ayrıca aşk cevherine ancak layık olanlar temas edebilir. O yüzden de dünyevi ve maddi olandan kalbini temizleyebilen aşka layık olur:

Mevlânâ şiirlerinde defalarca aşkın bu özelliğine dikkat çeker:

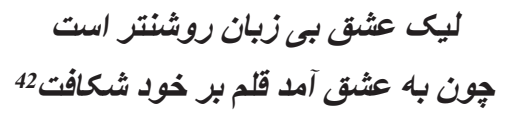

Dilin anlatımı daha açık olsa da

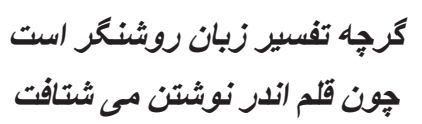

Dile gelmeyen aşk daha aydınlıktır Kalem yazarken koşup durduğundan Aşk bahsine gelince çatlayı aciz kalır

Makale, Araf suresi 172. Ayette ${ }^{43}$ Cenâb-1 Hakk'1n elest bezmine işaret etmesiyle devam ediyor. Aşk ve muhabbet bir tecelli şeklidir ve Cenâb-1 Hak arif kullarına kesintisiz bir 1şığa benzeyen aşk ile tecelli eder. Bu anlamda Mevlânâ şöyle demiştir:

39 Mevlânâ, Mesnevî, Üçüncü Defter, no:212

40 Yunus Emre, Divân, no:266

41 Mevlânâ, Mesnevî, Beşinci Defter, no: 115

42 Mevlânâ, Mesnevî, Birinci Defter, no:6

43 آلَستُ بِرَبَكُمَ (Ben sizin Rabbiniz değil miyim 


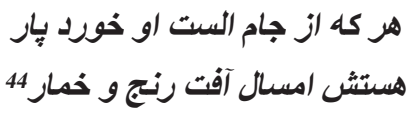

Elest kadehinden geçen yul içene

Bu yıl baş ağrısı ve sarhoşluk var

Yunus Emre ise şöyle demektedir:

\title{
Bir sâkîden içdük şarâb 'Arş'dan yüce meyhânesi \\ Ol sâkînün mestleriyüz cânlar anun peymânesi ${ }^{45}$
}

\begin{abstract}
Așk-ı Mecâzi ve Așk-ı Hakiki
Arifler aşkı genellikle mecazî ve hakiki olarak ikiye ayırmışlardır. Hakiki aşkta kemale, marifete ve yaratıcıya/gerçek maşuka ulaşma çabası vardır. Mecazi aşk ise dünyevidir ve fiziksel bir amacı vardır. Buna rağmen genellikle mecazî aşk hakiki aşkın emeli kabul edilmiştir. Çünkü mecazi aşk da insanı özüne yaklaştırır ve aslında dünyevi aşk da Mâşuk'un cemâlinden bir tecellidir.
\end{abstract}

Mevlânâ bu konuda şöyle demektedir

$$
\begin{aligned}
& \text { جون در زرادخانه باز شد } \\
& \text { غمزه هاى هُشم تير انداز شد بـ }
\end{aligned}
$$

Cephaneliğin kapısı açılınca

Gözün işmarı beni ok altında bıraktı

Yunus Emre:

'Işkın aldı benden beni

Ben yanaram düni güni
Bana seni gerek seni

Bana seni gerek seni ${ }^{47}$

\section{Mevlânâ ve Yunus Emre’de Vahdet-i Vücûd}

Heidârî Fatima - Dabîrân Hâkîmî ve Soltânî Manzour'un yazdığı, başlığııı "Yunus Emre'nin eserleri üzerinde Mevlânâ’nın Vahdet-i Vücûd Görüşünün Etkisi” olarak çevirebileceğimiz makalede, öncelikle Vahdet-i Vücud ekolüne değinilerek, İbn Arabi ekolün isim babası olmasa da, bu ekolü kuran kişi olarak kabul edildiği

44 Mevlânâ, Mesnevi, Beşinci Defter, no: 38

45 Yunus Emre, Divân, no:406

46 Mevlânâ, Mesnevî, Birinci Defter, no: 197

47 Yunus Emre, Divân, no: 381 
belirtilmektedir. Ariflere göre sadece Allah her şeyde söz sahibidir. İbn Arâbi fikhi ve dini kuralları bile vahdet-i vücûd esasına göre kabul etmektedir. Mevlânâ hiçbir zaman vahdet-i vücûd anlayışında olduğunu açıkça ifade etmemiştir. Ama İbn Arâbî ve Mevlânâ'ya göre her şey Allah'ın tecellisiyle oluşmaktadır. Âlem bir bütündür ve kesret vahdetin tecellisidir. ${ }^{48}$

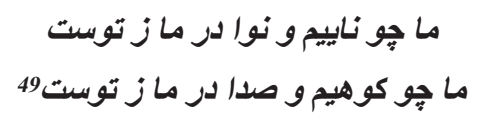

Biz ney gibiyiz namelerimiz sendendir

Biz dă̆ gibiyiz bizdeki yankı sendendir

Makalede bu örnekler sonucunda Mevlânâ'nın İbn Arâbî'den, Yunus Emre'nin de Mevlânâ'nın etkisiyle Vahdet-i Vücud ekolünün temsilcileri olduğunu söylenmektedir.

Hem Yunus Emre hem de Mevlânâ nefsi en zararlı düşmen olarak görmüşler ve onunla savaşmayı en önemli cihad olarak kabul etmişlerdir. Fatima Heidarî Mevlânâ ve Yunus Emre'de Nefs isimli makalesinde ise, Nefsin özünün anlaşılamamasının sebebinin, özünün başka bir âleme ait olması olduğunu ifade etmiş. Bu dünyada nefsi tanıyabilecekler ancak ölmeden önce ölebilenlerdir diyerek Mevlânâ'dan şu örneği vermektedir:

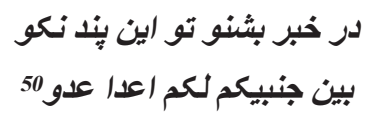

Hadisteki şu güzel nasihata kulak ver

\section{En kötü düşmanınız iki yanınızın ortasındadır}

Fatima Heidari makalesinde Yunus Emre'nin Mevlânâ'nın müridi gibi olduğunu söyleyerek Yunus Emre'nin de nefs konusunda Mevlânâ gibi düşündüğünü ifade etmektedir. $^{51}$

Mevlânâ:

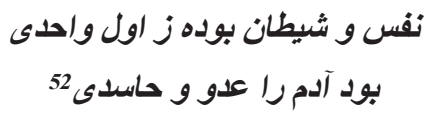

48 Fatima Heidarî- Hâkîmî Dâbîrân ve Manzour Soltânî, Tesir-i Nigeriş-i Vahdet-i Vücûdi Mâbane-i Mevlânâ Celâleddin-i Belhî der Asâr-ı Yunus Emre, ( Neşriye-yi Edebîyât-1 Tatbikî: h.ş. 1396), 17

49 Mevlânâ, Mesnevî, Birinci Defter, no:29

50 Mevlânâ, Mesnevî, Beşinci Defter, no:195

51 Heidari Fatima, Mevlânâ ve Yunus Emre'de Nefs, s.4

52 Mevlânâ, Mesnevî, Üçüncü Defter, no:150 


\section{(Nefs ve şeytan evvelden birdiler, Adem'e kıskançlık ve düşmanlık beslemekteydiler)}

Yunus Emre:

\section{Her kim kendüyi gördi üstâdı iblîs oldı}

\section{Kişi ne buldıyısa miskinligile buld ${ }^{53}$}

Zannımızca mutasavvıf şairlerin ortak bir bakış açısıyla ele aldıkları başlıklardan olan nefs konusu hakkında, Mevlânâ ve Yunus Emre'nin benzer bir görüş içinde olmaları, Yunus Emre'nin Mevlânâ'nın müridi olduğunu düşünmemize yeterli bir veri sağlamamaktadır.

\section{Sonuç}

Araştırmamızda, İran'da, M. Sadîk'in yayıma hazırladığı Yunus Emre'nin Türkçe Divânı dışında Yunus Emre ile ilgili telif bir kitaba ve teze rastlayamadık. Hayatı konusunda da fazla çalışma yapılmamıştır. N. Muhammedî ve Makhouh Maghsoudi'nin Yunus Emre'nin hayatıyla ilgili makaleleri vardır. Ancak Yunus Emre ile ilgili en farklı iddialar, Alevi ve Ehl-i Hak törenleriyle nesilden nesile geçen şifahi kültürle Yunus Emre'nin tanındığını söyleyen M. Sadik'e aittir. Yunus Emre ile ilgili Türkçeden ve Almancadan Farsçaya tercüme edilen bazı kitaplar bulunmaktadır. İran'da yazılan Yunus Emre ve Mevlânâ ile ilgili makalelerde ise Yunus Emre, Mevlânâ ve Sa'dî, Vahdet-i vücud, nefs, aşk, ilahi aşk, nasihat ve ahlaki risaleler bağlamında ele alınmaktadır. İran'da bugüne kadar Talat S. Halman, Mehmed Fuad Köprülü, Mustafa Tatçı, İskender Pala'nın Yunus Emre ile ilgili kitapları ile Mustafa Özçelik'in bir hikâyesinin Farsça'ya tercüme edildiği görülmektedir. İran'da Yunus Emre ile ilgili yazılan makalelerde ise Hicabi Kırlangıç ve Ramazan Rezaei Yunus Emre'yi Sa'dî ile karşılaştırmıştır. Ramazan Rezai iki şairin ortak konu başlıklarını karşılaştırarak benzerliklere makalesinde yer vermiş. Hicabi Kırlangıç ise bu iki şairin benzerlikleriyle birlikte, örneğin ahlaki bir eser olmasına rağmen Sa'dî Gülistan isimli eserinde hikayelere yer verirken, Yunus Emre'nin eserlerinde hikayelere yer vermediğinin altını çizerek, her iki şairin de kendine özgü bir üslubu olduğunu söylemiştir. Yunus Emre ve Mevlânâ’yı karşılaş̧ırarak inceleyen ve ortak bir makale yazan Fatima Heidarî,- Hâkîmî Dabîrân ve Manzour Soltanî ise iki şairi vahdet-i vücûd- aşk konusunda karşılaştırmış, Yunus Emre'nin Mevlânâ'dan oldukça etkilendiğini ifade etmişlerdir. Hosseini Arian ve Leily Abbasî Montazerî iki şairin aşka bakışını, Fatima Heidarî bir başka makalesinde iki şairin şiirindeki nefs konusunu ele alarak, Yunus Emre'nin

53 Yunus Emre, Divân, no:367 
Mevlânâ'nın bir müridi gibi olduğunu söylemektedirler. Bize göre ise Yunus Emre Mevlânâ'dan etkilenmiş olsa bile, Yunus Emre'ye Mevlânâ'nın takipçisi demek doğru olmayacaktır. Çünkü iki şair arasında benzerlik kurulan konular genellikle tüm mutasavvıf şairlerin ortak bakışla ele aldığı konuların yansımasıdır ve her iki şairin de kendine özgü bir üslubu bulunmaktadır.

Zannımızca tüm bu çalışmalardan sonra ortaya çıkan tabloda, Yunus Emre'nin Sa'dî, Hâfız ve özellikle de Mevlânâ ile benzer bir bakışa sahip olmasına ve benzer konu başlıklarını ele almasına rağmen, kendi tarzında özel bir üslup ve dil oluşturmayı başardığıdır. Köprülünün de dediği gibi Yunus Emre bir sanat dehasıdır ve Türk edebiyatı tarihinde orijinal bir edebiyat, bir halk edebiyatının kurucusu olmuştur.

İran'da Yunus Emre ile alakalı son derece sınırlı çalışmalar olduğunu görüyoruz. Temennimiz bundan sonrası için Yunus Emre şiir şerhleri ile Yunus Emre yılı münasebetiyle sayısı artan çalışmaların Farsçaya da tercüme edilmesidir. Hem telif eser hem tez olarak Yunus Emre'nin daha çok çalışılması ümidiyle.

Hakem Değerlendirmesi: Dış bağımsız.

Çıkar Çatışması: Yazar çıkar çatışması bildirmemiştir.

Finansal Destek: Yazar bu çalışma için finansal destek almadığını beyan etmiştir.

Peer-review: Externally peer-reviewed.

Conflict of Interest: The author has no conflict of interest to declare.

Grant Support: The author declared that this study has received no grant support.

\section{Kaynakça/References}

Arian Hosseini -Montazeri ve Leily Abbasî, "Mefhum-i Iş̧k Ez Dîdgâh-ı Mevlânâ ve Yunus Emre", (Tahran: Faslnâme-yi Mutaale-yi Edebiyyat-1 Tatbikî, h.ş. 1393), 29: 108-128.

Ebu Abdullah Muslihuddin Sa'di-i Şirâzi (691/1292), "Külliyât-ı Sa'dî, tashih. Muhammed Ali Furuğ̂̀”, (Tahran: İntişârât-1 Hermes, h.ş. 1385).

Golkarian, Kadir, “Guzide-i Eşâr-ı İrfani-yi Yunus Emre”, (Tebrîz: Neşr-i Yârân, h.ş. 1387).

Hace Şemseddin Muhammed Hâfız-1 Şîrâzî, "Divân”, Haz. Muhammed Kazvinî, Kâsım Ganî, (Tahran: İntişarat-1 Kaknüs, h.ş.1380 ).

Halman, Talat “Şair-i İnsangeray-ı Turk”, Tercüme: Vahid İmam, (Tahran: Muassasah-i Farhangi-yi Mantaghey, h.ş.1355).

Heidârî, Fatima, "Tahlil-i Tatbîk-i "Nefs" Der Asâr-ı Mevlânâ ve Yunus Emre", (Tahran: Neşriye-yi Mutalaat-i Şehrîyâr-i Pejuheşî, h.ş. 1399), 471-490.

Heidârî, Fatima- Dabîrân Hâkîmî ve Soltânî Manzour, "Tesir-i Nigeriş-i Vahdet-i Vücûd-i Mâbane-i Mevlânâ Celâleddin-i Belhî der Asâr-ı Yunus Emre", (Kirmân: Neşriye-yi Edebîyât-1 Tatbikî, h.ş.1396) 41-59. 
Hicâbî Kırlangıç, Asâr-1 Yunus Emre ve Sa'dî Ez Nazar-1 Sûret ve Muhtevâ, (Şîrâz: Neşriye-yi Sa'dî Şinâsî, h.ş.1393), 17:31

Huseynalizâde, Siyamak, “Işsk Işı̆̆ı", Yunus Emre'den Seçme İlahiler, (Tebriz: İntişarât-1 Talâş h.ş.1377).

Köprülü, Mehmet Fuad, “Türk Edebiyatında İlk Mutasavvıflar”, (İstanbul: Alfa Yayınları, 2017)

Köprülü, Mehmed Fuad, "Sûfiyân-ı Nohustîn Der Edebiyat-ı Türk", Tercüme: Tevfîk Sobhanî, (Tahran: İntişârât-i Encümen-i Asar u Mefâhir-i Farhangî, h.ş. 1385).

Mahnâme-i Şems Nigâr, (Hoy: h.ş. 1395), 4

Makhrouh Maksoudî, Yunus Emre, Şâir-i Turk,(Meşhed: Mecelle-i Tahsisi-i Zebân u Edebiyâ-1 Dânişkede-i Edebiyât u Ulûm-i İnsânî, h.ş. 1383), 3: 69-86

Mevlânâ Celâleddin-i Muhammed Belhî (672/1273), "Divân-ı Kebîr", Tashih: Nizâmeddîn Nurî, (Tahran: İntişârât-ı Kitâb-ı Abân, h.ş. 1387), c. 1-2

Muhammedî, Nâsır, “Yunus Emre Şair-i Şuride-i Turk”, (Tahran: Neşr-i Nâme-i Farhang, h.ş. 1370), 4: 85-89.

Schimmel, Annemarie, “Ba Yunus Emre Der Rah”, Almanca aslından tercüme: Mahrokh Maghsoudi, (Tahran: Dayereh-i Farhang, h.ş. 1363).

Tatçı, Mustafa, Yunus Emre, “Türkiye Diyanet Vakfi İslam Ansiklopedisi”, ( İstanbul: TDV Yayınlar, 2013), 43: 600-606.

Tatç1, Mustafa, "Yunus Şair: Guzerî ber Zindegî ve Asâr Ahvâl-i Yunus Emre Nohustîn Şaîr-i Bozorg-i Edebiyyat-ı Türkî”, Tercüme: Aydin Farangî,( Erdebil: Neşr-i Unvan, h.ş. 1392).

Özçelik, Mustafa, "Raz-ı Gol-i Sorh”, (Faslnâme-Gurûb: h.ş.1397) say1: 9.

Sadîk, H. Muhammed, "Yunus Emre- Divân-ı Eşâr-ı Türkî, (Tahran: İntişârât-1 Tek Draht, h.ş. 1394).

Rezaei, Ramazan, “Der Amedî-yi Ber Mezamin-i Ahlaki-yi Ez Didgâh-ı Sa'dî ve Yunus Emre”, (Mecmue-i Dânişgâh-i Muhakkık-i Erdebilî, 4-6 Şehriver mah, h.ş.1394), 1-10.

Yunus Emre, "Divân”, Hazırlayan: Mustafa Tatç1, T.C. Kültür ve Turizm Bakanlığı, e-kitap, ISBN 978-975-17-3342-9.

http://www.drsadigh.ir/\%D9\%85\%D8\%B5\%D8\%A7\%D8\%AD\%D8\%A8\%D9\%87\%D9\%87\%D8\%A7/972-\%D9\%85\%D8\%B5\%D8\%A7\%D8\%AD\%D8\%A8\%D9\%87

https://ganjoor.net/moulavi/masnavi 